\title{
Use of Mental State Words of School-Aged Children with High-Functioning Autism Spectrum Disorder
}

\author{
Eunjin Yang ${ }^{\mathrm{a}}$, Yoonkyoung Lee ${ }^{\mathrm{b}}$ \\ ${ }^{a}$ Department of Speech Pathology E Audiology, Graduate school of Hallym University, Chuncheon, Korea \\ ${ }^{b}$ Division of Speech Pathology and Audiology, Hallym University, Chuncheon, Korea
}

Correspondence: Yoonkyoung Lee, PhD Division of Speech Pathology and Audiology, Hallym University, 1 Hallimdaehak-gil, Chuncheon 24252, Korea

Tel: +82-33-248-2219

Fax: +82-33-256-3420

E-mail: ylee@hallym.ac.kr

Received: January 20, 2020

Revised: February 13, 2020

Accepted: February 19, 2020

This work was supported by the National Research Foundation of Korea (NRF) grant funded by the Korea government (MSIT) (No. 2019R1A2C2006010).
Objectives: The limited social-emotional ability of children with autism spectrum disorder children's can affect language use. This study aimed to investigate the use of mental state words in school-aged children with high-functioning autism spectrum disorder (HF-ASD). Methods: The participants were 10 school-aged children with HF-ASD, 10 typically developing children matched for chronological age with the HF-ASD children (CA group), and 10 typically developing children matched for language age with the HF-ASD children (LA group). Language samples were collected through an individual interview procedure using ADOS-2 (Autism Diagnostic Observation Schedule-2) questions. The total number of words (TNW), number of different words (NDW), and TNW and NDW according to the type of mental state word per utterance were measured. Results: The HF-ASD group showed a significant difference in TNW and NDW of mental state words compared to the CA group; and did not show a significant difference from the LA group in both. Regarding the TNW and NDW by subcategories of mental state words, there was a significant difference between the HF-ASD group and the CA group. Conclusion: The results of the study confirmed that the limited use of mental state words is maintained even after the children with autism spectrum disorder enter school age. The results of this study have implications for language and social communication assessment and intervention of school-aged children with high-functioning autism spectrum disorder.

Keywords: High-functioning autism spectrum disorder (HF-ASD), Mental state word, Total number of word (TNW), Number of different word (NDW)
사람들은 일상적인 대화에서 자신 혹은 타인의 마음에 대해 이 야기한다. 이 때, 사람들은 믿음, 의도, 동기 바람처럼 눈으로 관찰 할 수 없는 정신상태와 관련된 언어를 사용한다. 예를 들어, "그 때 화가 났어." "제 주위 사람들은 다 행복하다는 걸 느껴요.” 등 감정 이나 생각과 같은 표현들이 의사소통에서 많이 사용된다. 이처럼 자신이나 다른 사람의 바람, 의도, 믿음 또는 여러 종류의 정서나 동 기와 같은 사람의 심리적, 내적 상태를 설명해주는 어휘를 정신상 태용어(mental state word)라고 한다(Miller \& Aloise, 1989).

일반적으로 아동들은 정신상태용어를 2 세 말부터 산출하기 시 작하여 3 세에는 산출 빈도가 상당히 증가한다(Bretherton \& Beeghly, 1982; Shatz, Wellman, \& Shilber, 1983). 이후에도 연령이
증가하면서 정신상태용어 사용 능력은 지속적으로 발달하여, 4,5 세경에 아동들은 정신상태용어를 의사소통 상황에서 능숙하게 사 용할수 있게 된다(Gwon, \& Lee, 2009; Hughes \& Dunn, 1998).

이러한 정신상태용어를 습득하고 사용하는 능력은 인지적, 사 회-정서적 발달, 특히 다른 사람들의 마음을 이해하는 마음이론 능 력과 관련된다(Lee, Lee, \& Shin, 2004; Lee, \&, Lee, 2006). 마음이 론은 다른 사람의 정신상태를 파악하거나 이해하고 다른 사람과 자신을 연결하는 것을 의미(Lee et al., 2004)하는 것으로 이 능력은 정신상태용어 습득이나 사용에 영향을 줄 수 있다고 보고된다 (Lee et al., 2004). 따라서 정신상태용어 사용 능력은 마음이론 능력 이 발달하면서 함께 발달하게 되고, 반대로 아동들은 정신상태용 
어를 사용함으로써 상대방의 마음을 더 잘 이해할 수 있게 되어 서 로 상호적인 영향을 갖는다.

그러나자폐스펙트럼장애 아동은 사회-정서적 측면에서 주된 결 함을 가지며 특히, 다른 사람의 마음이나 자신의 마음을 이해하거 나, 정서, 생각 등을 표현하는데 어려움을 갖는다(Seo, 2002; Kim, $\& \mathrm{Han}, 2005)$. 이처럼 상대의 마음을 이해하는 것에서 어려움을 보 이는 자폐스펙트럼장애의 특성은 정신상태용어 사용과 같은 언어 사용에도 영향을 미칠 수 있다. 일부 연구자들은 자폐스펙트럼장 애 아동이 의사소통상황에서 정신상태용어를 사용하는 능력이 일반 아동과 차이를 보이는지에 대해 관심을 가지고 연구 하였다 (Park, \& Lee, 2001; Tager-Flusberg, 1992). Tager-Flusberg (1992)는 자폐스펙트럼장애 아동의 정신상태용어 사용 특성을 생활연령 및 언어연령을 일치한 다운증후군 아동과 비교하여 살펴보았다. 다운 증후군 아동과 비교한 이유는 같은 발달 장애를 가지지만 특히 사 회-정서적인 측면에서 차이를 보이는 집단이기 때문이었다. 이 연 구에서는 아동이 좋아하는 주제로 대화를 하여 발화를 수집하였 고 수집된 발화에서 정신상태용어를 '바람, 지각, 정서, 인지' 네 가 지 범주로 나누어 측정하였다. 바람은 자신이 바라는 것을 표현하 는 어휘들로 '원하다, 희망하다'와 같은 어휘가 포함되었으며, 정서 는 '울다, 안다, 웃다’와 같은 정서를 표현하는 행동을 나타내는 어 휘들과 ‘화나다, 좋다, 행복하다'와 같이 정서 상태를 표현하는 어휘 들이 포함되었다. 지각은 5 가지 감각을 나타내는 어휘들로 '듣다, 보 다'와 같은 어휘가 포함되었으며, 인지는 사고나 생각을 표현하는 어휘들로 '믿다, 생각하다’와 같은 어휘가 포함되었다. 연구 결과, 자 폐스펙트럼장애 아동은 정신상태용어의 총 낱말 수에서는 다운증 후군 아동과 차이를 보이지 않았으나, 하위 범주 별로 살펴보았을 때에는 바람 영역에서만 자폐스펙트럼장애 아동이 유의하게 많이 사용한다고 보고하였다.

국내 아동을 대상으로 한 Park과 Lee (2001) 연구에서는 정신 연 령이 5-6세인 자폐스펙트럼장애 아동의 정신상태용어 사용을 언 어 연령을 일치시킨 일반 아동과 비교하여 살펴보았다. 이 연구에 서는 마음이론 중재에서 사용된 4장면의 글자 없는 그림자료 10 가 지를 사용하여 발화를 수집하였으며, 수집된 발화에서 사용된 정 신상태용어의 총 낱말 수와 다른 낱말 수를 측정하였다. 정신상태 용어는 Tager-Flusberg (1992) 연구에 따라 분석하였다. 연구 결과, 자폐스펙트럼장애 아동이 일반아동에 비해 정신상태용어의 총 낱 말 수와 다른 낱말 수가 유의하게 낮다고 보고하였다. 또한 이 연구 에서 하위 범주는 차이 검정을 진행하지 않았으나, 네 가지 범주 모 두 자폐스펙트럼장애 아동이 정신상태용어를 더 적게 사용하였고 바람 범주에서 제일 큰 차이를 보고하였다.
앞에서 제시한 선행연구들을 살펴보면, 주로 다운증후군 아동 과 비교한 Tager-Flusberg (1992)에서는 정신상태용어의 총 낱말 수에서 차이를 보고하지 않았고, 하위 범주 중 바람에서만 자폐스 펙트럼장애 아동이 더 많은 용어를 사용한다고 보고하였다. 반면, Park과 Lee (2001) 연구에서는 정신상태용어의 총 낱말 수와 다른 낱말 수에서 자폐스펙트럼장애 아동이 더 적은 어휘를 사용한다 고 보고하였으며, 이러한 연구결과를 통해 자폐스펙트럼장애 아동 의 사회-정서적인 결함이 실질적으로 정신상태용어 사용에 영향 을 줄수 있다는 것을 확인하였다.

그러나 앞서 보고한 연구들은 주로 7세 이전의 어린 아동이나 기 능 수준이 낮은 아이들을 대상으로만 연구가 진행되었다. 하지만 자 폐스펙트럼장애 아동들의 문제는 이 시기에만 집중된 것이 아니며 이후까지도 계속되고, 언어문제는 기능 수준이 낮은 아동만이 아니 라 기능 수준이 높은 아동들에서도 사회적 맥락에서 계속 그 차이 들이 보고되고 있다(Tager-Flusberg, Paul, \& Lord, 2005). 또한 정 신상태용어는 인지, 사회-정서적인 발달과 관련됨으로 해당 어휘 의 습득 시기로 알려진 4-5세 이후에도 일상생활에서 다른 사람의 마음에 대해 이야기하거나 자신의 생각을 표현하기 위해 빈번하게 사용된다. 그럼에도 불구하고 습득 시기 이후나 기능 수준이 높은 아동들의 정신상태용어 사용 양상에 대해 살펴본 연구는 드물다.

본 연구에서는 이상을 배경으로 학령기에 있는 고기능 자폐스펙 트럼장애 아동이 정신상태용어를 사용하는데 일반 아동과 차이를 보이는지 살펴보고자 하였으며, 다양한 어휘 사용에 있어서도 일 반 아동과차이를 보이는지 알아보고자 하였다.

\section{연구방법}

\section{연구대상}

본 연구는 초등학교에 재학 중인 고기능 자폐스펙트럼장애 아동 10 명, 언어연령을 일치시킨 일반 아동 10 명과 생활연령을 일치시킨 일반 아동 10 명으로 총 30 을 대상으로 하였다.

고기능 자폐스펙트럼장애 아동은 자폐스펙트럼장애 아동 중에 서 지능과 언어 능력이 정상 수준에 해당하는 아동으로 대학 병원 이나 종합병원 소아정신과 전문의에 의해 자폐스펙트럼장애로 진 단받거나 의심된다고 보고된 아동 중에서 Autism Diagnostic Observation Schedule-Second Edition (ADOS-2; Lord, Rutter, DiLavore, Risi, Gotham, \& Bishop, 2012) Module 3과 사회적 의사소 통 설문지(SCQ; Yoo, 2008) 검사 결과 자폐스펙트럼장애에 해당하 는 아동으로 하였다. ADOS-2 검사의 경우, 훈련 과정을 통해 자격 을 갖춘 검사자가 평가 및 채점을 진행해야 하기 때문에 본 연구에 
서는 ADOS-2 심화과정을 이수하여 자격증을 취득한 검사자에 의 해 평가된 결과를 사용하였다. 지능은 한국 비언어 지능검사-2 (KCTONI-2; Park, 2014)에서의 지능지수가 80 이상인 아동으로 하였 으며, 언어 능력은 수용·표현 어휘력 검사(Receptive \& Expressive Vocabulary Test, REVT; Kim, Hong, Kim, Jang, \& Lee, 2009) 중 표현어휘력 검사 결과가 10 백분위수 이상에 해당하고, 학령기 아 동 언어검사(Language Scale for School-aged Chidren, LSSC; Lee, Heo, \& Jhang, 2015) 중 ‘단락듣기 이해’, '문법 판단 및 수정' 문항 검사의 결과가 환산점수 10 점 내외(-1 SD 이상)에 해당하는 아동으 로 하였다.

일반 아동은 부모와 주 양육자 및 교사에 의해 발달이 정상적으 로 이루어졌다고 보고된 아동 중에서 사회적 의사소통 설문지 (SCQ; Yoo, 2008) 검사 결과 자폐스펙트럼장애에 해당하지 않는 아동으로 하였으며, 지능은 한국 비언어 지능검사-2 (K-CTONI-2; Park, 2014)에서 지능지수가 80 이상인 아동으로 하였다. 언어 능력 은 수용·표현 어휘력 검사(REVT; Kim et al., 2009) 중 표현어휘력 검사 결과가 10 백분위수 이상에 해당하고, 학령기 아동 언어검사 (LSSC; Lee et al., 2015) 중 ‘단락듣기 이해', '문법 판단 및 수정’문항 검사의 결과가 환산점수 10 점 내외(-1 SD 이상)에 해당하는 아동으 로 하였다. 이 중에서 생활연령 일치 아동 집단은 고기능 자폐스펙 트럼장애 아동과 일대일로 대치시켰을 때, 같은 학년에 속하는 아 동이었으며, 언어연령 일치 아동 집단은 고기능 자폐스펙트럼장애
아동과 일대일로 대치시켰을 때, REVT 표현어휘 검사 결과 등가 연 령이 일치하는 아동으로 하였다.

자폐스펙트럼장애 아동을 선별하는 검사에서 고기능 자폐스펙 트럼장애 아동 집단과 생활연령 일치 아동 집단 및 언어연령 일치 아동 집단은 모두 SCQ 점수에서 유의한 차이를 보였다. 그러나 고 기능 자폐스펙트럼장애 아동 집단과 생활연령 일치 아동 집단의 생활연령과 고기능 자폐스펙트럼장애 아동 집단과 언어연령 일치 아동 집단의 REVT로 측정한 언어연령은 통계적으로 유의한 차이 가 없었다. 연구 대상의 정보는 Table 1과 같다.

\section{자료 수집 도구}

자료 수집 도구는 Autism Diagnostic Observation Schedule-Second Edition (ADOS-2; Lord, et al., 2012) Module 3의 절차에서 포 함된 인터뷰 질문을 일부 수정 및 보완하여 사용하였다. ADOS-2 는 자폐스펙트럼장애로 의심되는 아동을 위해 아동의 사회적 또는 의사소통적 행동 관찰을 위한 표준화된 검사이다. 이 검사의 인터 뷰 질문에는 아동의 심리 상태를 묻는 질문이 다수 포함되어 있어 정신상태용어를 살펴보기에 적합하다고 판단되어 본 연구에서 사 용하였다. ADOS-2의 인터뷰는 크게 3가지의 영역 '감정' '사회적 어려움과 괴로움, '친구/관계/결혼' 영역과 각 영역의 세부 주제로 구성되어 있다. 본 연구에서는 기존의 질문에 감정의 의미를 정의하 거나 타인의 감정 혹은 경험 등에 대한 질문을 추가하였으며, 정신

Table 1. Participants' characteristics

\begin{tabular}{|c|c|c|c|c|}
\hline & HFASD $(\mathrm{N}=10)$ & $C A(N=10)$ & $\mathrm{LA}(\mathrm{N}=10)$ & $p$ \\
\hline Chronological age (mo) & $120.10(22.06)$ & $122.10(19.19)$ & $107.00(16.18)$ & .184 \\
\hline Age range & $7 ; 8-12 ; 6$ & $8 ; 0-12 ; 2$ & $6 ; 9-10 ; 10$ & - \\
\hline Grade range & $2-6$ & $2-6$ & $1-5$ & - \\
\hline \multicolumn{5}{|l|}{ Autism diagnostic test } \\
\hline SCO & $21.60(4.62)$ & $1.30(0.94)$ & $1.60(1.26)$ & .000 \\
\hline ADOS-2 total score & $13.40(3.59)$ & - & - & - \\
\hline \multicolumn{5}{|l|}{ Language test } \\
\hline REVT-R language age (mo) & $129.80(37.46)$ & $150.20(44.29)$ & $123.90(30.11)$ & .279 \\
\hline REVT-E-language age (mo) & $127.50(30.51)$ & $156.90(41.41)$ & $126.90(31.90)$ & .109 \\
\hline LSSC USP standard score & 9.40 (3.30) & $10.80(1.47)$ & $10.70(2.05)$ & .362 \\
\hline LSSC GEL standard score & $9.10(2.23)$ & $11.50(1.43)$ & $11.30(1.41)$ & .008 \\
\hline LSSC GER standard score & $8.80(1.39)$ & $10.70(2.16)$ & $10.60(2.11)$ & .062 \\
\hline \multicolumn{5}{|l|}{ Intelligence test } \\
\hline K-CTONI-2 & $96.60(10.75)$ & $101.70(13.22)$ & $105.80(16.10)$ & .329 \\
\hline
\end{tabular}

Values are presented as mean (SD).

HFASD= high functioning autism spectrum disorders; $C A=$ chronological age-matched; $L A=$ language age-matched; $A D O S-2=$ Autism Diagnostic Observation Schedule-second edition (Lord et al., 2012); REVT=Receptive and Expressive Vocabulary Test (Kim et al., 2009); LSSC=Language Scale for School-aged Children (Lee et al., 2014); USP= understanding spoken paragraph; GEJ= grammatical error judgement; GER= grammatical error revision; K-CTONI-2=Korean version of Comprehensive Test of Nonverbal Intelligence second edition (Park, 2014). 
상태용어 하위 범주가 고르게 사용될 수 있도록 각 질문에 하위 질 문을 보완하였다. 보완된 내용은 언어병리학 박사 2명에게 적절성 을 확인 받았다. 수정한 인터뷰 질문이 아동의 수준에 적절한지 판 단하고 수집되는 발화의 양이 어느 정도인지 확인하기 위해 2 명의 일반 아동에게 예비연구를 진행하였다. 예비연구를 진행한 결과, 얻어진 발화 수가 매우 적거나 아동에게 심각한 심리적인 부담을 주거나, 아동의 연령에 적합하지 않은 문항은 제외하였다. 따라서 본 연구에서는 '감정'에 대한 영역과 '사회적 어려움과 괴로움' 영역 중 '놀림과 괴롭힘', '친구/관계/결혼' 영역 중 '친구'에 해당하는 주 제만 인터뷰 질문으로 선정하였다. 연구에 사용한 질문은 Appen$\operatorname{dix} 1$ 에 제시하였다.

\section{자료 수집 절차}

본 연구의 절차는 한림대학교 생명윤리심의위원회에서 승인을 받아 진행하였다(HIRB-2019-037). 연구자는 인터넷 커뮤니티 카 페 등에 대상자 모집 안내를 게시하여 대상자를 모집하였으며, 모 집된 아동의 가정 및 언어발달센터를 방문하여 연구를 진행하였 다. 인터뷰를 실시하기 전 연구자는 고기능 자폐스펙트럼장애 대상 자와 일반 아동이 연구 대상자에 적합한지 확인하기 위해 대상자 선정을 위한 검사를 먼저 실시하였다. 사회적 의사소통 설문지 (SCQ; Yoo, 2008)는 아동의 부모님에게 작성법을 설명한 후 검사지 에 체크하도록 하였으며, ADOS-2 (Lord et al, 2012)는 최근 1-2년 이내에 검사를 받았던 결과가 있는 7명의 아동은 검사를 생략하였 고, 검사 결과가 없는 3 명의 아동 만을 대상으로 실시하였다. 아동 의 지능이 80 이상인지 확인하기 위해 한국 비언어 지능검사-2 (KCTONI-2; Park, 2014)를 실시하였고, 언어 수준을 확인하기 위해 수용·표현 어휘력 검사(REVT; Kim et al., 2009)와 학령기 아동 언 어검사(LSSC; Lee et al., 2015)를 실시하였다.

본 검사는 기본 검사 결과 본 연구의 대상자로 적절하다고 판단 된 아동 만을 대상으로 진행하였다. 본 검사를 진행하기 전에 아동 이 오랜 시간의 검사로 피로해 보이는 경우 10 분간의 휴식 시간을 가진 다음 인터뷰를 시작하였다. 연구자는 아동에게 "이제 선생님 이 00 이의 기분이나, 친구들에 관련해서 질문할 거에요. 생각나는 대로 대답해주면 돼요.”라고 말하여 아동에게 절차를 설명한 후 인 터뷰를 진행하였다. 아동이 절차를 이해했다고 판단되면, 연구자 는 정서와 관련된 영역부터 아동에게 질문하기 시작하였고, 아동 이 말하는 동안에는 “응, 그래”와 같이 중립적인 반응으로 반응하 였다. 각 질문에서 아동이 끝맺는 말을 하거나 더 이상 이야기 할 것 이 없다는 행동을 보이면 다음 질문으로 인터뷰를 진행하였다.

\section{자료 전사 및 분석}

본 검사자료는 모두 녹음전용 MP3 (ICD-UX533F)를 사용하여 녹음 하였으며, 자료 수집 후 연구자가 1 주일 이내에 전사하였다. 전 사 완료 후, 전체 전사자료 중에서 아동의 불명료한 발화의 경우는 분석 자료에서 제외하였다. 분석 자료에서 발화는 Kim (1997)의 발 화 구분 원칙에 따라 구분하였다.

정신상태용어는 Tager-Flusberg (1992)에서 제시한 기준을 참고 하여 4 가지의 범주와 각 범주 별 하위 범주를 분석하였다. 정신상 태용어의 4 가지 범주는 바람, 지각, 정서, 인지였다. 각 범주에 대한 정의는 Bartsch와 Wellman (1989), Bretherton과 Beeghly (1982)를 참고하였다. 바람은 대화적 사용, 정신상태, 기타의 하위 범주로 나 누었고, 지각은 5 가지 감각을 언급하는 지각과 주의, 기타로 하위 범주를 나누었다. 정서는 행동, 의향, 감정적 상태, 기타로 하위 범주 를 나누었고, 인지는 관용적 표현, 대화적 사용, 정신상태, 기타로 하위 범주를 나누었다. 정신상태용어의 분류 및 조작적 정의는 Appendix 2에 제시하였다.

\section{자료의 측정}

분석된 자료에서는 아동이 산출한 정신상태 용어의 총 낱말 수 (TNW), 다른 낱말 수(NDW), 하위 범주 별 총 낱말 수(TNW)와 다른 낱말 수 $(\mathrm{NDW})$ 를 측정하였다. 세 집단 간 아동들 간에 발화 량에는 유의한 차이가 없었으나, 모든 아동들이 산출한 발화 수가 동일하지는 않았으므로 각 아동 별로 발화 수를 분모로 총 낱말 수 (TNW)와 다른 낱말 수(NDW)를 측정하였다. 세 그룹의 발화량은 Table 2와 같다.

정신상태용어가 아동 본인이나 다른 사람의 정신상태를 표현하 기 위해 사용된 경우만을 측정에 포함하였으며, 검사자의 말을 확 인하기 위한 목적으로 되풀이 한 경우는 측정에서 제외하였다. 또 한 아동이 무의미하게 같은 어휘를 반복한 경우에는 한 번만 측정 하고, 나머지는 제외하였다.

본 연구의 측정치는 다음과 같다.

\section{발화당 정신상태용어의 총 낱말 수(TNW)}

발화에서 아동이 사용한 정신상태용어의 전체 빈도로 아동이 사용한 전체 정신상태용어를 전체 발화수로 나누어 측정하였다.

Table 2. Number of utterance of the three groups

\begin{tabular}{lcccc}
\hline & $\operatorname{HFASD}(\mathrm{N}=10)$ & $\mathrm{CA}(\mathrm{N}=10)$ & $\mathrm{LA}(\mathrm{N}=10)$ & $F$ \\
\hline Number of utterance & $98.9(53.34)$ & $74.5(46.64)$ & $81(21.27)$ & .428 \\
\hline Values are presented as mean $(\mathrm{SD})$. & & &
\end{tabular}


발화당 정신상태용어의 다른 낱말 수(NDW)

발화에서 아동이 사용한 정신상태용어의 전체 어휘 유형 수로 아 동이사용한 전체 어휘 유형 수를 전체 발화수로 나누어 측정하였다. 발화당 하위 범주 별 정신상태용어의 총 낱말 수(TNW)

하위 범주인 바람, 지각, 정서, 인지에서 아동이 사용한 정신상태 용어의 전체 빈도로 각 범주 별 아동이 사용한 정신상태용어를 전 체 발화수로 나누어 측정하였다.

\section{발화당 하위 범주 별 정신상태용어의 다른 낱말 수(NDW)}

하위 범주인 바람, 지각, 정서, 인지에서 아동이 사용한 정신상태 용어의 총 어휘 유형 수로 각 범주 별 아동이 사용한 어휘 유형 수 를 전체 발화수로 나누어 측정하였다.

\section{신뢰도}

자료 분석에 대한 신뢰도는 연구자와 평가자 간의 일치도로 측정 하였다. 평가자는 언어병리학을 전공하는 대학원생이었으며, 신뢰 도를 측정하기 전에 검사 절차, 기록 방법, 분석 방법에 대한 설명을 듣고 1 명의 자료로 연습하였다. 연구자와 평가자 간의 불일치한 항 목은 연구자와 다시 확인하고 조정하여 최대한 일관적으로 분석할 수 있도록 하였다. 분석 연습이 끝난 후에 연구자는 전체 자료의 $10 \%$ 를 무작위로 추출하여 평가자가 독립적으로 분석하게 하였다. 신뢰도는 연구자와 평가자가 분석한 내용에서 일치한 반응의 수를 일치한 반응의 수와 일치하지 않은 반응의 수의 합으로 나누어 100 을 곱하여 계산하였다. 그 결과 일치도는 정신상태용어의 총 낱말 수(TNW)는 95\%, 정신상태용어의 다른 낱말 수(NDW)는 98.3\% 로 측정되었으며, 하위 범주 별 정신상태용어의 총 낱말 수(TNW) 를 측정하였을 때, 바람 범주는 $100 \%$, 지각 범주는 $96 \%$, 정서 범주 는 92.5\%, 인지 범주는 96.7\%로 측정되었다. 마지막으로 하위 범주 별 정신상태용어의 다른 낱말 수(NDW)를 측정하였을 때, 바람 범 주는 $100 \%$, 지각 범주는 $100 \%$, 정서 범주는 $100 \%$, 인지 범주는 $91.7 \%$ 로 측정되었다.

Table 3. TNW and NDW per utterance of mental state words among the three groups

\begin{tabular}{lcccc}
\hline & HFASD $(\mathrm{N}=10)$ & $\mathrm{CA}(\mathrm{N}=10)$ & $\mathrm{LA}(\mathrm{N}=10)$ & $F$ \\
\hline TNW per utterance & $0.37(0.15)$ & $0.73(0.30)$ & $0.51(0.14)$ & $7.043^{* *}$ \\
NDW per utterance & $0.17(0.70)$ & $0.33(0.13)$ & $0.28(0.88)$ & $5.990^{* *}$ \\
\hline
\end{tabular}

Values are presented as mean (SD).

HFASD = high functioning autism spectrum disorders; $C A=$ chronological agematched; $L A=$ language age-matched; $T N W=$ total number of words; NDW= number of different words.

${ }^{* *} p<.01$.

\section{통계처리}

아동 집단 간의 정신상태용어 산출 특성을 살펴보기 위하여 SPSS(Version 25)를 활용하여 일원배치 분산분석(one-way ANO$\mathrm{VA}$ )를 실시하였으며. 통계적으로 유의미한 차이가 난 경우 Scheffe 사후 분석을 실시하였다.

\section{연구결과}

\section{정신상태용어의 발화당 총 낱말 수(TNW) 및 다른 낱말 수(NDW)}

정신상태용어의 발화당 총 낱말 수 $(F=7.043, p=.003)$ 와 다른 낱말 수 $(F=5.990, p=.007)$ 모두 집단 간 유의한 차이가 나타났고, 집단 간 차이는 정신상태용어의 발화당 총 낱말 수(TNW)와 다른

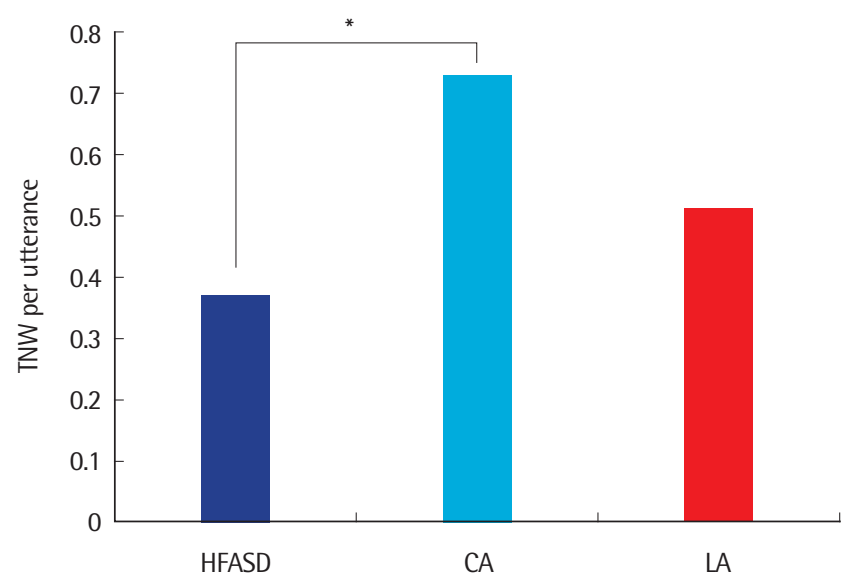

Figure 1. TNW per utterance of mental state words among the three groups. TNW $=$ total number of words. ${ }^{*} p<.05$.

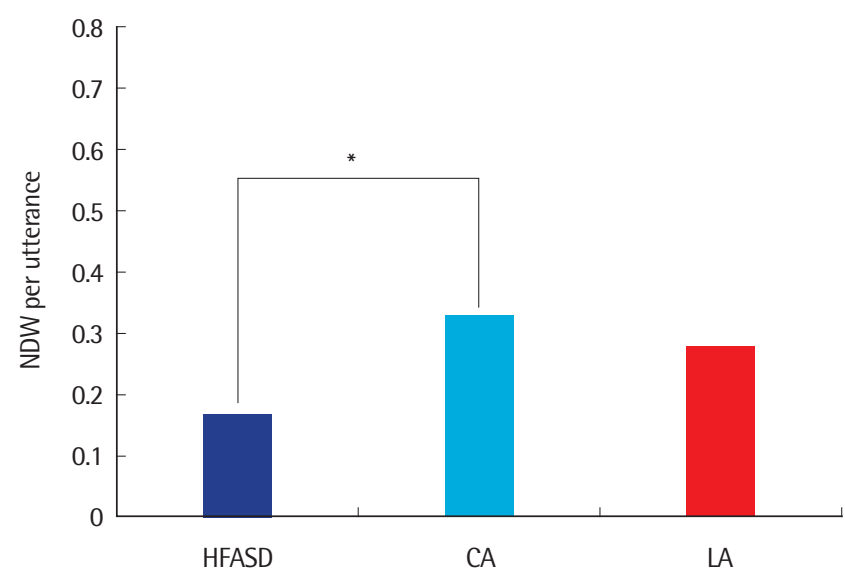

Figure 2. NDW per utterance of mental state words among the three groups. NDW $=$ number of different words. ${ }^{*} p<.05$. 
Table 4. TNW and NDW per utterance of mental state word according to word subtype among three groups

\begin{tabular}{lcccc}
\hline & HFASD $(\mathrm{N}=10)$ & $\mathrm{CA}(\mathrm{N}=10)$ & $\mathrm{LA}(\mathrm{N}=10)$ & $F$ \\
\hline TNW per utterance & & & & \\
$\quad$ Desire & $0.01(0.02)$ & $0.01(0.01)$ & $0.02(0.02)$ & .341 \\
Perception & $0.04(0.02)$ & $0.08(0.04)$ & $0.07(0.03)$ & 3.342 \\
Emotion & $0.17(0.07)$ & $0.39(0.21)$ & $0.27(0.08)$ & $5.773^{* *}$ \\
Cognition & $0.13(0.15)$ & $0.25(0.16)$ & $0.14(0.08)$ & 2.232 \\
NDW per utterance & & & & \\
Desire & $0.00(0.00)$ & $0.00(0.01)$ & $0.01(0.01)$ & .692 \\
Perception & $0.02(0.01)$ & $0.03(0.01)$ & $0.03(0.001)$ & 3.125 \\
Emotion & $0.10(0.05)$ & $0.22(0.12)$ & $0.17(0.05)$ & $5.990^{* *}$ \\
Cognition & $0.03(0.02)$ & $0.06(0.02)$ & $0.05(0.03)$ & 1.841 \\
\hline
\end{tabular}

Values are presented as mean (SD).

HFASD = high functioning autism spectrum disorders; $C A=$ chronological age matched; $L A=$ language age-matched; $T N W=$ total number of words; $N D W=$ number of different words.

${ }^{* *} p<.01$.

낱말 수(NDW) 모두 고기능 자폐스펙트럼장애 집단과 생활연령 일치 집단 간의 차이인 것으로 나타났다 $(p<.05)$. 정신상태용어의 총 낱말 수와 다른 낱말 수에 대한 결과는 Table 3 과 Figure 1, Figure 2에 제시하였다.

\section{정신상태용어의 하위 범주 별 발화당 총 낱말 수(TNW) 및 다른 낱말 수(NDW)}

정신상태용어의 하위 범주 중 정서 범주의 발화당 총 낱말 수 $(F=5.773, p=.008)$ 와 다른 낱말 수 $(F=5.990, p=.007)$ 에서만 집 단 간 유의한 차이가 나타났다. 정서 범주의 발화당 총 낱말 수 (TNW)와 다른 낱말 수(NDW) 모두 집단 간 차이는 고기능 자폐 스펙트럼장애 집단과 생활연령 일치 집단 간의 차이인 것으로 나타 났다 $(p<.05)$. 그러나 바람, 지각, 인지 범주의 발화당 총 낱말 수 (TNW)와 다른 낱말 수(NDW)에서는 집단 간 유의한 차이가 나 타나지 않았다(Table 4, Figure 3, Figure 4).

\section{논의 및 결론}

자폐스펙트럼장애 아동이 정신상태용어 사용에서 제한을 보일수 있다는 것은 일부 연구를 통해서 보고되었다. 그러나 선행연구들은 주로 정신상태용어를 습득하는 시기인 4-5세 아동이나 기능 수준이 낮은 아동을 대상으로 연구되었다. 하지만 정신상태용어는 습득된 이후에도 일상적인 의사소통 상황에서 많이 사용된다. 따라서 본 연 구에서는 학령기 고기능 자폐스펙트럼장애 아동들을 대상으로 사 용양상을 중심으로 정신상태용어사용특성을 살펴보고자하였다.

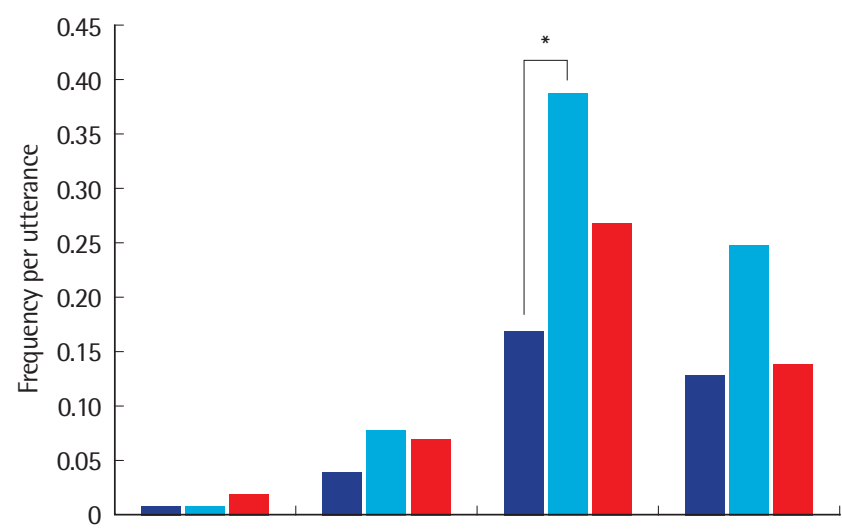

Figure 3. TNW per utterance of mental state word according to word subtype among the three groups.

TNW $=$ total number of words.

${ }^{*} p<.05$.

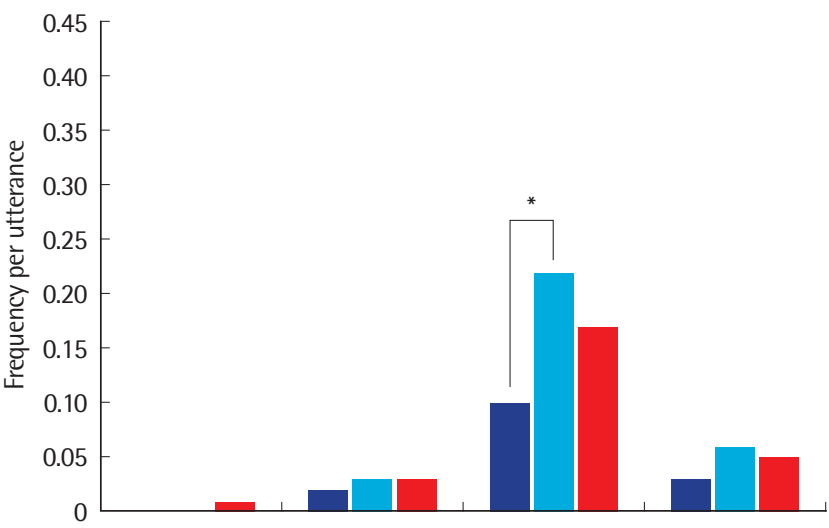

Figure 4. NDW per utterance of mental state word according to word subtype among the three groups.

NDW $=$ number of different words.

${ }^{*} p<.05$.

\section{정신상태용어의 총 낱말 수(TNW) 및 다른 낱말 수(NDW)}

먼저 고기능 자폐스펙트럼장애 집단이 사용한 정신상태용어의 총 낱말 수(TNW) 및 다른 낱말 수(NDW)를 전체 발화수로 나누 어 언어연령 일치 집단, 생활연령 일치 집단과 비교하였다. 그 결과, 정신상태용어의 발화당 총 낱말 수(TNW)에서 고기능 자폐스펙 트럼장애 아동은 생활연령 일치 아동보다 유의하게 더 적은 어휘 를 사용하는 것으로 나타났으며, 언어연령 일치 집단과는 유의한 차이를 보이지 않았다.

이러한 결과는 자폐스펙트럼장애 아동의 경우 학령기에 접어든 이후까지도 같은 연령의 또래에 비해 정신상태용어를 사용하는데 제한을 보이는 것을 나타낸다. 자폐스펙트럼장애 아동들의 정신상 태용어 사용을 언어연령을 일치시킨 아동들과 비교한 선행연구인 
Park과 Lee (2001)의 연구에서도 일관된 결과를 보고하였다. Park 과 Lee (2001)는 정신연령이 5-6세에 있는 아동을 대상으로 언어연 령을 일치시킨 일반 아동과 비교하여 정신상태용어 사용을 살펴보 았다. 그러나 이 연구에서는 본 연구와 달리 연령이 어리고 기능 수 준이 낮은 집단을 대상으로 하였다. 본 연구에서는 학령기에 있는 고기능 자폐스펙트럼장애 아동을 대상으로 하였다는 것을 고려해 보았을 때 정신상태용어의 사용은 연령이 어리고 기능 수준이 낮 은 자폐스펙트럼장애 집단만이 아니라 학령기에 해당하고 기능 수 준이 높은 자폐스펙트럼장애 아동들도 지속적으로 결함을 가진다 는 것을 보여주는 결과라고 할 수 있다.

또한 본 연구에서는 생활연령 일치 집단 아동과의 비교에서만 유 의미한 차이가 나타났고, 언어연령 일치 집단과의 비교에서는 유의 미한 차이가 나타나지 않았다. 그러나 기술통계를 살펴보면 언어연 령 일치 집단의 정신상태용어 사용 빈도가 자폐스펙트럼장애 아동 에 비해 높게 나타난 것을 확인할 수 있었다. 본 연구에서 세 집단을 통제하기 위해 실시했던 REVT (Kim et al., 2009) 결과를 살펴보면 유의한 차이는 나타나지 않았으나 자폐스펙트럼장애 집단이 언어 연령 일치 집단보다 더 나은 수행을 보였다. 그러나 어휘력이 아닌 다른 언어영역을 살펴본 LSSC (Lee et al., 2015)에서는 자폐스펙트 럼장애 집단이 생활연령 일치 집단과 언어연령 일치 집단보다 더 낮 은 수행을 나타냈다. 본 연구의 대상자 특성에서도 나타난 것처럼 자폐스펙트럼장애 아동은 다른 언어에 비해 상대적으로 어휘력에 서 더 나은 수행을 보인다는 것이 많이 보고되고 있다(Choi, Oh, \& Lee, 2015; Tager-Flusberg et al., 2005). 이러한 결과에 따르면 자폐 스펙트럼장애 아동은 전반적인 어휘에서는 좋은 수행을 보일 수 있 으나, 정신상태용어를 사용하는데 있어서는 제한될 수 있으며, 어 휘력보다는 다른 언어능력과 비슷한 경향을 보인다는 것을 나타내 는 결과일 수 있다.

정신상태용어 사용은 인지나 사회-정서적 능력과 밀접하게 관련 되며, 특히 정신상태용어를 사용하려면 자신은 물론 타인의 생각 이나 관점, 믿음 등을 고려할 수 있어야 한다(Lee et al., 2004; Lee \& Lee, 2006). 하지만 자폐스펙트럼장애 아동은 흔히 마음이론 능력 에서 제한을 보이고(Seo, 2002; Kim \& Han, 2005), 사회적 의사소 통과 사회적 상호작용에서 지속적인 결함을 보이는 특성을 갖는다 (American Psychiatry Association, 2013). 본 연구에서도 학령기 고기능 자폐스펙트럼장애 아동을 대상으로 했음에도 불구하고 정 신상태용어를 사용하는데 제한을 보인 것은 사회적 상호작용이나 마음이론 능력에서 결함을 보이는 자폐스펙트럼장애 특성이 정신 상태용어를 사용하는 능력에 지속적으로 영향을 미치는 것으로 볼수 있다.
정신상태용어의 발화당 다른 낱말 수(NDW)에서도 발화당 총 낱말 수(TNW)와 마찬가지로 고기능 자폐스펙트럼장애 아동이 생활연령 일치 아동에 비해 유의하게 적은 것으로 나타났다. 다른 낱말 수(NDW)는 아동이 한 발화에서 같은 어휘를 여러 번 중복 해서 사용했더라도 한 번만 측정하게 된다. 그렇게 때문에 정신상 태용어의 총 낱말 수(TNW)는 아동이 정신상태 용어를 얼마나 자 주 사용하는가를 반영한다면 다른 낱말 수(NDW)는 아동이 사용 한 낱말이 얼마나 다양한지를 반영해준다(Lee \& Heo, 2013).

본 연구에서 나타난 결과는 정신상태용어의 발화당 총 낱말 수 (TNW)와 마찬가지로 발화당 다른 낱말 수(NDW)에서도 아동이 실제 의사소통 상황에서 사용하는 정신상태용어가 단순히 사용 빈도만 적은 것이 아니라 동일 연령의 또래에 비해 제한된 어휘를 사용한다는 것을 의미한다. 또한 발화당 총 낱말 수(TNW)와 다른 낱말 수(NDW) 모두 고기능 자폐스펙트럼장애 아동이 언어수준 이 비슷한 아동에 비해서도 더 적은 정신상태용어를 사용하는 경 향을 보이고 있다. 이러한 결과는 자폐스펙트럼장애 아동이 가지고 있는 어휘 자체가 부족하거나, 정신상태 어휘를 어휘집(lexicon)에 가지고 있더라도 실제 사용할 때에는 제한된 어휘 만을 사용하는 경향을 보이는 것으로도 해석해 볼 수 있다.

종합하면 고기능 자폐스펙트럼장애 아동은 정신상태용어의 발 화당 총 낱말 수(TNW)와 다른 낱말 수(NDW)모두 생활연령 일 치 일반 아동보다 유의하게 적게 나타났으며, 기술통계 결과에서 언어연령 일치 일반 아동보다도 상대적으로 적게 나타났다. 이러한 결과는 자폐스펙트럼장애 아동은 일반적으로 정신상태용어를 습 득한다고 보고된 연령 이후에도 언어적 의사소통 상황에서 정신상 태용어를 제한되게 사용하고, 사용하는 어휘 목록도 또래에 비해 제한된다는 것을 보여 주며 자폐스펙트럼장애 아동들의 제한된 사 회-정서 능력과 관련될 수 있음을 시사한다.

\section{정신상태용어의 하위 범주 별 발화당 총 낱말 수(TNW) 및 다른 낱말 수(NDW)}

세 집단 아동이 사용한 정신상태용어를 바람, 지각, 정서, 인지 네 개의 하위범주로 나누어 비교한 결과 하위 범주 별로 사용된 발 화당 총 낱말 수(TNW)는 바람, 지각, 인지 범주에서 유의미한 차 이가 나타나지 않았으나, 정서 범주에서만 유의미한 차이가 나타났 다. 정서 범주는 고기능 자폐스펙트럼장애 아동이 생활연령을 일 치시킨 아동에 비해 정서에 관한 어휘를 더 적게 사용하는 것으로 나타났다. 정서 범주 이외의 범주들의 기술통계 결과를 살펴보면 인지, 지각, 바람 순서로 차이가 큰 것으로 나타났다.

본 연구와 같이 자폐스펙트럼장애 아동의 정신상태용어를 바람, 
지각, 정서, 인지 네 개의 하위 범주로 나누어 비교한 연구에서 Tager-Flusberg (1992)는 다운증후군 아동과 비교하였을 때, 바람 범주 에서만 자폐스펙트럼장애 아동이 어휘를 유의하게 더 많이 사용하 였다고 보고하였다. 또한 일반 아동과 비교한 Park과 Lee (2001)연 구에서는 기술통계 결과를 통해서만 바람 범주에서의 차이가 가 장 크게 나타났으며, 자폐스펙트럼장애 아동이 일반 아동에 비해 더 적은 어휘를 사용한다고 보고하였다. Tager-Flusberg (1992) 연 구와 Park과 Lee (2001) 연구에서 모두 바람 영역에서만 두드러진 차이를 보고 한 것에 비해, 본 연구에서는 정서 범주의 어휘에서만 유의미한 차이를 보고하여 선행연구와 차이를 보이는 결과를 나타 냈다. 이러한 연구결과는 본 연구의 연구대상이 선행연구들에 비 해 연령이 높은 학령기 아동이었고, 자폐스펙트럼장애 아동의 기 능 수준도 선행연구보다 높은 아동을 대상으로 하였음을 고려해 볼 수 있다. 언어 의사소통 발달에서는 나이가 어리거나 기능 수준 이 낮은 아동의 경우 정서나 인지를 나타내는 표현보다는 욕구나 바람을 표현하는 목적으로 용어를 사용한다(Lee \& Lee, 2016). 선 행연구들에서는 언어 수준이 취학 전 시기에 해당하는 아동들을 대상으로 하였기 때문에 상대적으로 바람을 표현하는 어휘에서 차 이를 보이는 것으로 나타났을 수 있으나, 본 연구에서는 학령기 아 동을 대상으로 하였으며, 기능 수준이 높은 아동을 대상으로 하였 기 때문에 선행연구들에 비해 정서나 인지 어휘의 사용이 많았을 수 있고 따라서 정서 어휘의 사용에서 유의미한 차이가 나타났을 것으로 볼 수 있다.

또한 Tager-Flusberg (1992)는 자폐스펙트럼장애 아동들이 초기 에 발달하는 단순한 정서나 이를 표현하는 어휘 사용에서는 차이 가 없을 수 있으나 이후에 습득되는 상대적으로 복잡한 정서에서 는 어려움을 겪을 수 있다고 하였다. 본 연구에서는 생활연령이나 발달연령이 영유아 시기에 해당하는 아동들을 대상으로 한 선행 연구에 비해 연령이 높고 지능 및 언어능력이 제한되지 않는 아동 을 대상으로 하였기 때문에 다양하고 세분화되어 복잡한 인지적 정서를 표현하는 능력에서는 제한을 보이는 것으로 볼 수 있다.

정신상태용어의 하위 범주 별 다른 낱말 수(NDW)에서도 하위 범주 별 총 낱말 수(TNW)와 마찬가지로 바람, 지각, 인지 범주에서 는 유의미한 차이가 나타나지 않았으나, 정서 범주에서는 고기능 자폐스펙트럼장애 아동이 생활연령을 일치시킨 일반 아동에 비해 다른 낱말 수(NDW)가 적게 나타났다. 이러한 결과는 하위 범주 별 총 낱말 수(TNW)와 마찬가지로 하위 범주 별 다른 낱말 수 $(\mathrm{NDW})$ 에서도 고기능 자폐스펙트럼장애 아동이 동일 연령의 또래 에 비해 정서 범주의 어휘를 적게 사용할 뿐 아니라 제한된 어휘를 반복적으로 의미하는 것으로 전체 어휘 유형 수(NDW)와 마찬가
지로 자폐스펙트럼장애 아동이 정서 어휘 자체를 적게 가지고 있을 수 있으며, 또는 정서 어휘를 어휘집(lexicon)에 가지고 있다고 할지 라도 실제 사용할 때에는 다양한 어휘를 사용하지 못하는 것으로 볼수 있다.

본 연구는 고기능 자폐스펙트럼장애 아동의 정신상태용어 사용 특성을 살펴보기 위해 연구를 진행하였으며, 고기능 자폐스펙트럼 장애 아동이 정신상태용어를 사용하는데 제한을 보인다는 결과 를 확인하였다. 이 연구의 결과를 종합해 보았을 때, 고기능 자폐스 펙트럼장애 아동은 생활 연령을 일치시킨 일반 아동에 비해 더 적 은 정신상태용어를 사용하였고, 사용하는 어휘 유형 수도 적게 나 타났다. 또한, 정신상태용어 중에서도 바람, 지각, 인지 범주보다 정 서 범주 어휘를 더 적게 사용하였으며, 사용하는 어휘 유형 수도 적 게 나타났다. 이러한 결과는 사회적 의사소통에서 결함을 갖고 감 정 표현이나 상대의 마음을 잘 이해하지 못하는 자폐스펙트럼장애 의 특성이 아동의 어휘 사용에 영향을 미친 것으로 볼 수 있다.

따라서 본 연구에서는 학령전기 아동을 대상으로 하거나 기능 수준이 낮은 아이들을 대상으로 진행한 선행연구와 달리 학령기 고기능 자폐스펙트럼장애 아동을 대상으로 하여 학령기 고기능 자폐스펙트럼장애 아동도 지속적으로 정신상태용어를 사용하는 데 어려움을 보인다는 것을 확인할 수 있었다. 이러한 결과는 정신 상태용어가 습득되는 시기 이후의 연령에서 고기능 자폐스펙트럼 장애 아동의 정신상태용어 사용 특성에 대한 정보를 제공해 줄 수 있을 것이다. 또한 본 연구에서는 정신상태용어의 전체 사용 빈도 와 어휘 유형 수만 살펴보았던 선행연구와는 달리 정신상태용어의 하위 범주에 따라서 산출되는 어휘 유형 수에서도 아동의 기능 수 준에 따라 차이를 보일 수 있음을 확인하였다. 추후 연구에서는 자 폐스펙트럼장애 아동의 기능 수준에 따라서 정신상태용어의 하위 범주 용어 사용에서 어떠한 차이를 보이는지 확인할 필요가 있을 것이다.

\section{REFERENCES}

American Psychiatric Association. (2013). Diagnostic and statistical manual of mental disorders. Arlington: American Psychiatric Publishing.

Bartsch, K., \& Wellman, H. (1989). Young children's attribution of action to beliefs and desires. Child development, 60(4), 946-964.

Bretherton, I., \& Beeghly, M. (1982). Talking about internal states: the acquisition of an explicit theory of mind. Developmental psychology, 18(6), 906.

Choi, J., Oh, S. J., \& Lee, Y. (2015). Language Characteristics of School-aged Children with High-functioning ASD through the LSSC. Special Edcation 
Research, 14(2), 139-156.

Gwon, E. Y., \& Lee, H. (2009). Desire and belief in every conversation of Korean children: evidence from language production data. Korean Journal of Child Studies, 30(6), 567-581.

Hughes, C., \& Dunn, J. (1998). Understanding mind and emotion: longitudinal associations with mental-state talk between young friends. Developmental psychology, 34(5), 1026-1037.

Kim, D. Y., \& Han, S. H. (2005). A study of executive function deficits and theory of mind in high-functioning autistic children. The Korean Journal of Early Childhood Special Education, 5(1), 25-45.

Kim, Y. T. (1997). Study on utterance length in 2-4 year-old Korean children. Korean Journal of Communication Disorders, 2(1), 5-25.

Kim, Y. T., Hong, G. H., Kim, K. H., Jang, H. S., \& Lee, J. Y. (2009). Receptive \& expressive vocabulary test (REVT). Seoul: Seoul Community Rehabilitation Center.

Lee, Y., \& Lee, H. (2016). Development of Intentional Communicative Behavior in Korean Toddlers 12 to 30 Months. Communication Sciences \& Disordsrs, 21(4), 553-566.

Lee, Y., Heo, H., \& Jhang, S. (2015). Language Scale for School-aged Children (LSSC). Seoul: Hakjisa.

Lee, Y. K. \& Heo, S. (2013). Word production in spontaneous speech of school-aged children with autism spectrum disorders: A abstractness in noun and verb. Journal of the Korean Association for Persons with Autism, 13(3), 1-17.

Lee, Y. J., \& Lee, J. (2006). Young children's use of mental state terms in narratives according to the levels of narrative development, theory of mind, and vocabulary. The Journal of Korea Open Association for Early Childhood Education, 11(1), 153-178.

Lee, Y. J., Lee, J. S., \& Shin, E. S. (2004). Differences in young children's levels of language functions of pretend play, vocabulary, and mental state term expressions for young children according to the theory of mind. International Journal of Early Childhood Education, 24(4), 141-160.

Lord, C., Rutter, M., DiLavore, P., Risi, S., Gotham, K., \& Bishop, S. (2012). Autism Diagnostic Observation Schedule-2nd edition (ADOS-2). Los Angeles, CA: Western Psychological Corporation.

Miller, P. H., \& Aloise, P. A. (1989). Young children's understanding of the psychological causes of behavior: a review. Child development, 60(2), $257-$ 285.

Park, H. (2014). Korean version of Comprehensive Test of Nonverbal Intelligence Second Edition-2 (K-CTONI-2). Seoul: Mindpress.

Park, H. O., \& Lee, S. H. (2001). Using words related to psychological-internal states in children with and without autism. Korean Journal of Communication \& Disorders, 6(2), 392-405.

Seo, G. H. (2002). Intervention of theory of mind deficits in children with high functioning autistic disorder and asperger disorder. Journal of Emotional Disturbances \& Learning Disabilities, 18(3), 37-64.

Shatz, M., Wellman, H. M., \& Silber, S. (1983). The acquisition of mental verbs: a systematic investigation of the first reference to mental state. Cognition, 14(3), 301-321.

Tager-Flusberg, H. (1992). Autistic children's talk about psychological states: deficits in the early acquisition of a theory of mind. Child Development, 63(1), 161-172.

Tager-Flusberg, H., Paul, R., \& Lord, C. (2005). Language and communication in autism. In F. R. Volkmar et al. (Eds.), Handbook of autism and pervasive developmental disorders (3rd ed., pp. 335-364). Hoboken, NJ: John Wiley \& Sons.

Yoo, H. J. (2008). Korean version of Social Communication Questionnaire (SCQ). Seoul: Hakjisa. 
Appendix 1. 인터뷰 질문

\begin{tabular}{|c|c|}
\hline 인터뷰 주제 & 질문 \\
\hline \multicolumn{2}{|l|}{ 감정 } \\
\hline \multirow[t]{7}{*}{ 행복 } & 1. 행복하다고 느낀 적 있어요? \\
\hline & 2. 언제 행복하다고 느꼈어요? \\
\hline & 3. 행복하다는 건 어떤 걸 말하는 거 같아요? \\
\hline & 4. 행복하려면 어떻게 해야 할까요? \\
\hline & 5. 그렇게 하면 왜 행복해져요? \\
\hline & 6. 다른 사람들도 행복하다고 느낄까요? \\
\hline & 7. 다른 사람들은 언제 행복할까요? \\
\hline \multirow[t]{8}{*}{ 두려움 } & 1. 두려움을 느낀 적 있어요? \\
\hline & 2. 언제 두렵다고 느꼈어요? \\
\hline & 3. 두렵다는 건 어떤 걸 말하는 거 같아요? \\
\hline & 4. 두렵다는 게 뭐라고 생각해요? \\
\hline & 5. 두려움을 느낄 때 나아지려면 어떻게 해요? \\
\hline & 6. 왜 그렇게 하면 기분이 나아져요? \\
\hline & 7. 다른 사람들도 두려움을 느낄까요? \\
\hline & 8. 다른 사람들은 언제 두려움을 느낄까요? \\
\hline \multirow[t]{7}{*}{ 화남 } & 1. 화났다고 느낀 적 있어요? \\
\hline & 2. 언제 화난다고 느꼈어요? \\
\hline & 3. 화난다는 건 어떤 걸 말하는 거 같아요? \\
\hline & 4. 화가 났다고 느낄 때 나아지려면 어떻게 해요? \\
\hline & 5. 왜 그렇게 하면 기분이 나아져요? \\
\hline & 6. 다른 사람들도 화난다는 걸 느낄까요? \\
\hline & 7. 다른 사람들은 언제 화가 난다고 느낄까요? \\
\hline \multirow[t]{7}{*}{ 슬픔 } & 1. 슬프다고 느낀 적이 있어요? \\
\hline & 2. 언제 슬프다고 느꼈어요? \\
\hline & 3. 슬프다는 건 어떤 걸 말하는 거 같아요? \\
\hline & 4. 슬프다고 느낄 때 나아지려면 어떻게 해요? \\
\hline & 5. 왜 그렇게 하면 기분이 나아지나요? \\
\hline & 6. 다른 사람들도 슬프다는 걸 느낄까요? \\
\hline & 7. 다른 사람들은 언제 슬프다고 느낄까요? \\
\hline \multirow[t]{7}{*}{ 외로움 } & 1. 외롭다고 느낀 적이 있어요? \\
\hline & 2. 언제 외롭다고 느꼈어요? \\
\hline & 3. 외롭다는 건 어떤 걸 말하는 거 같아요? \\
\hline & 4. 외롭다고 느낄 때 나아지려면 어떻게 해요? \\
\hline & 5. 왜 그렇게 하면 기분이 나아지나요? \\
\hline & 6. 다른 사람들도 외롭다는 걸 느낄까요? \\
\hline & 7. 다른 사람들은 언제 외롭다고 느낄까요? \\
\hline \multirow[t]{7}{*}{ 편안함 } & 1. 편안하다고 느낀 적 있어요? \\
\hline & 2. 언제 편안하다고 느꼈어요? \\
\hline & 3. 편안하다는 건 어떤 걸 말하는 거 같아요? \\
\hline & 4. 편안하려면 어떻게 해야 할까요? \\
\hline & 5. 그렇게 하면 왜 편안해져요? \\
\hline & 6. 다른 사람들도 편안하다고 느낄까요? \\
\hline & 7. 다른 사람들은 언제 편안할까요? \\
\hline \multirow{7}{*}{$\begin{array}{l}\text { 사회적 } \\
\text { 어려움과 } \\
\text { 괴로움 }\end{array}$} & 1. 놀림을 당하거나 괴롭힘을 당한 적이 있어요? \\
\hline & 2. 왜 놀림을 당한다고 생각했어요? \\
\hline & 3. 친구가 놀리거나 괴롭힐 때 어떻게 했어요? \\
\hline & 4. 놀림이나 괴롭힘을 당하는 걸 멈추게 하려고 해본 적이 있어요? \\
\hline & 5. 그렇게 하니까 어떻게 됐어요? \\
\hline & 6. 00 이가 다른 사람을 놀리거나 괴롭혔던 적 있어요? \\
\hline & 7. 놀림이나 괴롭힘을 당하는 다른 사람을 본 적이 있어요? \\
\hline
\end{tabular}

Appendix 1. Continued

\begin{tabular}{ll}
\hline 인터뷰 주제 & \multicolumn{1}{c}{ 질문 } \\
\hline 친구 & 1. 친구 있어요? \\
& 2. 친구에 대해서 이야기 해줄 수 있어요? \\
3. 그 친구는 00 (아동이름)이를 친구라고 생각해요? & 4. 어떻게 그걸 알았어요? \\
5. 그 친구들이랑은 어떻게 친해지게 됐어요? \\
6. 그 친구가 왜 00(아동이름)이 친구라고 생각해요? \\
7. 친구가 된다는 건 어떤 의미에요? \\
8. 친구랑 뭐 하는 걸 좋아해요? \\
9. 그 친구랑 얼마나 자주 만나요? \\
10. 그럼 그냥 학교에서 같이 공부하는 친구랑 00 (아동이름)이가 \\
친구라고 말하는 그 친구는 뭐가 달라요?
\end{tabular}

(Continued to the next) 
Appendix 2. 정신상태용어의 구분 및 정의

\begin{tabular}{|c|c|}
\hline 구분 & 정의 및 예시 \\
\hline 바람 & $\begin{array}{l}\text { 자신의 바람이 명시적이거나 암묵적으로 언급된 것으로 다음과 같은 내용으로 측정한다. } \\
\text { - 대화적 사용: 바람을 나타내는 용언이 사용되었으나 그 대상이 명백하게 표시되지 않은 경우(예: “자기가 원하는 걸 해야 해요”, “커피 마시면서 하고 싶은 } \\
\text { 거 할 때”) } \\
\text { - 정신상태: 바람을 나타내는 용언이 사용되었고 그 대상이 명백하게 표시된 경우 바람을 나타내는 경우(예: “일본 가고 싶다”) } \\
\text { - 기타: 용언이 사용되었으나 위의 두 가지 범주에 해당하지 않는 경우 }\end{array}$ \\
\hline 지각 & $\begin{array}{l}\text { 시각, 촉각, 청각, 미각, 후각의 } 5 \text { 가지 감각기를 통해 느끼는 상태를 표현한 것으로 다음과 같은 내용으로 측정한다. } \\
\text { - 지각: 감각을 표현하는 용언이 해당 감각기능을 표현하기 위해서 사용된 경우(예: “엄마, 아빠랑 축구 볼 때요") } \\
\text { - 주의: 감각을 표현하는 용언이 감각기능을 표현하기 위해서가 아니라 주의를 끌기 위한 목적으로 사용된 경우(예: “봐봐요”, “내 말 들어봐” 검사자의 주의 } \\
\text { 를 끌기 위한 목적으로 사용 } \\
\text { - 기타: 감각을 나타내는 용언이 사용되었으나 위의 두 가지 범주에 해당하지 않는 경우(예: “속이 아프다”, "엄마 말을 잘 듣자") }\end{array}$ \\
\hline 정서 & $\begin{array}{l}\text { 인과적 사건이나 상황과 관련하여 나타나는 감정적인 상태를 표현한 것으로 다음과 같은 내용으로 측정한다. } \\
\text { - 행동: 정서를 표현하는 용언이 그 정서를 표현하는 행동으로 사용된 경우(예: "기분이 나아지려면 울어요" "웃어야 해요") } \\
\text { - 정서 어휘의 한정적 사용: 정서를 표현하는 용언이 사람 또는 사물을 묘사하거나 사람 또는 사물에 대한 반응을 설명하기 위해 사용된 경우(예: “행복한 얼 } \\
\text { 굴”, “불편한 사람", "지루한 친구에요") } \\
\text { - 정서 어휘의 서술적 사용: 정서를 표현하는 용언이 인과적 사건이나 상황에 대한 정서적인 상태를 표현하기 위해 사용된 경우(예: "엄마가 예기 안 들어줘 } \\
\quad \text { 서 슬펐어요") } \\
\text { - 기타: 정서를 나타내는 용언이 사용되었으나 위의 세 가지 범주에 해당하지 않는 경우(예: “기분 좋은 거”, “무섭다는 거요") }\end{array}$ \\
\hline 이지 & 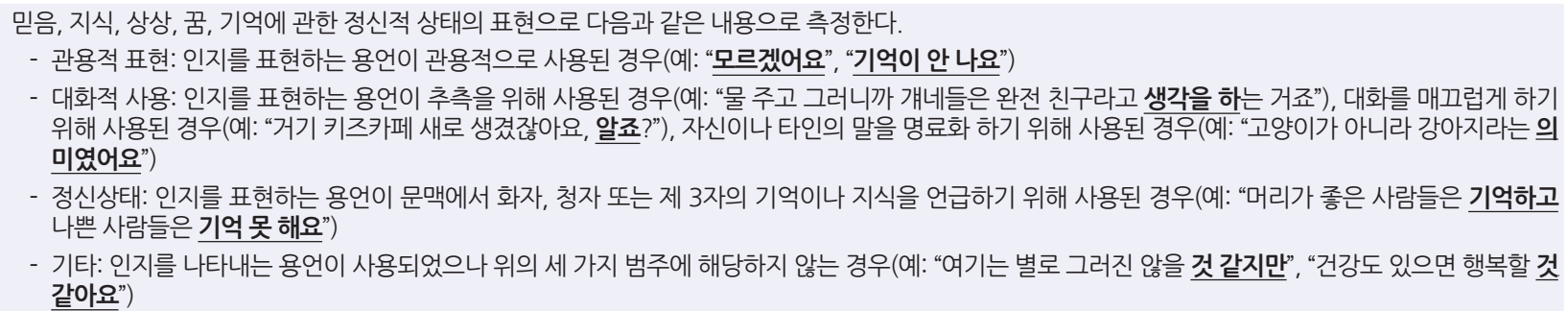 \\
\hline
\end{tabular}




\section{국문초록}

\section{고기능 자폐스펙트럼장애 초등학생의 정신상태용어 사용 특성}

양은진 $\cdot$ 이윤경

'한림대학교 일반대학원 언어병리청각학과, 2 한림대학교 언어청각학부

배경 및 목적: 자폐스펙트럼장애 아동들의 제한된 사회-정서적 능력은 언어 사용에 영향을 미칠 수 있다. 본 연구는 이를 확인하기 위 한 목적으로 학령기 고기능 자폐스펙트럼장애 아동의 정신상태용어 사용 특성을 살펴보고자 하였다. 방법: 연구에는 학령기 고기능 자폐스펙트럼장애 아동 10 명과 생활연령 일치 일반아동 10 명, 언어연령 일치 일반아동 10 명, 총 30 명이 참여하였다. 정신상태용어 확인 을 위해 인터뷰 절차를 통해 언어자료를 수집하였으며, 수집된 자료에서 발화당 정신상태용어의 총 낱말 수(TNW)와 다른 낱말 수 (NDW)를 측정하였고, 발화당 하위 범주 별 총 낱말 수(TNW)와 다른 낱말 수(NDW)를 측정하였다. 결과: 자폐스펙트럼장애 집단은 정신상태용어의 총 낱말 수(TNW)와 다른 낱말 수(NDW)에서 모두 생활연령 일치 일반아동 집단과 유의한 차이를 보였으며 언어연 령 일치 집단과는 유의한 차이를 보이지 않았다. 정신상태용어의 하위 범주 별 총 낱말 수(TNW)와 다른 낱말 수(NDW)에서는 정서 범주에서만 고기능 자폐스펙트럼장애 아동 집단과 생활연령 일치 일반아동 집단이 유의한 차이를 보였다. 논의 및 결론: 본 연구를 통 하여 자폐스펙트럼장애 아동들이 학령기에 접어든 이후에도 정신상태 용어 사용이 제한된다는 사실을 확인하였다. 본 연구의 결과는 학령기 고기능 자폐스펙트럼장애 아동의 어휘 평가 및 중재에 의미 있는 자료로 활용할 수 있을 것이다.

핵심어: 고기능 자폐스펙트럼장애, 정신상태용어, TNW, NDW

이 성과는 정부(과학기술정보통신부)의 재원으로 한국연구재단의 지원을 받아 수행된 연구임(No. 2019R1A2C2006010).

\section{참고문헌}

권은영, 이현진(2009). 한국 아동의 일상생활 대화에서 나타난 바람과 믿음 산출자료를 중심으로. 아동학회지, 30(6), 657-581.

김도연, 한소희(2005). 고기능 자폐아동의 실행기능과 마음이론에 관한 특성 연구. 유아특수교육연구, 5(1), 25-45.

김영태(1997). 한국 2-4세 아동의 발화길이에 관한 기초 연구. 언어청각장애연구, 2(1), 5-25.

김영태, 홍경훈, 김경희, 장혜성, 이주연(2009). 수용·표현 어휘력 검사(Receptive \& Expressive Vocabulary Test, REVT). 서울: 서울장애인종합복지관. 박현옥, 이소현(2001). 자폐아동과 일반아동의 심리적 상태에 대한 표현 어휘 능력 비교. 언어청각장애연구, 6(2), 392-405.

박혜원(2014). 한국 비언어 지능검사-2 (K-CTONI-2). 서울: 마인드프레스.

서경희(2002). 고기능 자폐아와아스퍼거 장애아의 마음 이론 결손과 중재. 정서·학습장애연구, 18(3), 37-64.

유희정(2008). 사회적 의사소통 설문지(The Social Communication Questionnaire, SCQ). 서울: 학지사.

이영자, 이종숙, 신은수(2004). 유아의 마음이론 수준에 따른 가장놀이의 언어기능 수준, 어휘력, 정신상태용어 사용능력 발달. 유아교육연구, 24(4), $141-160$

이영자, 이지현(2006). 유아의 개인적 - 가상적 내러티브에 나타난 정신상태 용어, 내러티브 수준, 마음이론, 어휘 수준에 관한 연구. 열린유아교육연 구, 11(1), 153-178.

이윤경, 이효주(2016). 12-30개월 영유아의 의도적 의사소통 행동 발달. 언어청각장애연구, 21(4), 553-566.

이윤경, 허상아(2013). 고기능 자폐범주성장애 초등학생의 구체어 및 추상어 산출: 명사와 동사를 중심으로. 자폐성장애연구, 13(3), 1-17.

이윤경, 허현숙, 장승민(2015). 학령기 아동 언어검사(Language Scale for School-aged Chidren, LSSC). 서울: 학지사.

최지은, 오소정, 이윤경 (2015). 학령기 고기능 자폐범주성장애 아동의 언어특성: 학령기아동언어검사(LSSC) 결과를 중심으로. 특수교육, 14(2), 139-156.

\section{ORCID}

양은진(제1저자, 대학원생 https://orcid.org/0000-0001-9601-8552); 이윤경(교신저자, 교수 https://orcid.org/0000-0002-9759-6247) 